\title{
Card Studies for Observational Research in Practice
}

Jobn M. Westfall, MD, MPH

Linda Zittleman, MSPH ${ }^{1}$

Elizabeth W. Staton, MS

Bennett Parnes, $M D^{1}$

Peter C. Smith, $M D^{1}$

Linda J. Niebauer

Douglas H. Fernald, $M A^{1}$

Javan Quintela, BS ${ }^{1}$

Rebecca F. Van Vorst, MSPH ${ }^{1,2}$

L. Miriam Dickinson, $P b D^{1}$

Wilson D. Pace, MD

'State Networks of Colorado Ambulatory Practices and Partners (SNOCAP), High Plains Research Network (HPRN), Colorado Research Network (CaReNet), Building InvestiGative practices for better Health Outcomes Research Network (BIG HORN), Department of Family Medicine, University of Colorado Denver School of Medicine, Aurora, Colorado

${ }^{2}$ Capital Adirondack Practice Based Research Network, Foundation for Healthy Living, Latham, New York

Conflicts of interest: authors report none.

\section{CORRESPONDING AUTHOR}

John M. Westfall, MD, MPH Department of Family Medicine F496, AO1

12631 E 17th Ave

Aurora, CO 80045-0508

Jack.westfall@ucdenver.edu

\begin{abstract}
PURPOSE Observational studies that collect patient-level survey data at the pointof-care are often called card studies. Card studies have been used to describe clinical problems, management, and outcomes in primary care for more than 30 years. In this article we describe 2 types of card studies and the methods for conducting them.
\end{abstract}

METHODS We undertook a descriptive review of card studies conducted in 3 Colorado practice-based research networks and several other networks throughout the United States. We summarized experiences of the State Networks of Colorado Ambulatory Practices and Partners (SNOCAP).

RESULTS Card studies can be designed to study specific conditions or care (clinicians complete a card when they encounter patients who meet inclusion criteria) and to determine trends and prevalence of conditions (clinicians complete a card on all patients seen during a period). Data can be collected from clinicians and patients and can be linked.

CONCLUSIONS Card studies provide cross-sectional descriptive data about clinical care, knowledge and behavior, perception of care, and prevalence of conditions. Card studies remain a robust method for describing primary care.

Ann Fam Med 2011;9:63-68. doi:10.1370/afm.1199.

\section{INTRODUCTION}

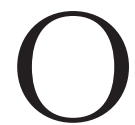
bservational and survey research continues to be an important source of information about primary care. Among the numerous methods available for gathering data about clinicians, patients, and their care, one method has persisted for more than 30 years and is considered by some to be the hallmark of practice-based research: the card study. A card study is a field-tested method for gathering data in the location where patients receive care by those who provide the care.

The card study method is designed to gather data at the point of care about such observable phenomena as disease incidence/prevalence, practice patterns, or clinical behaviors. Pioneered in the United States by the Ambulatory Sentinel Practice Network (ASPN) 30 years ago, card studies use short questionnaires that participating clinicians complete for patients with a specific condition. ${ }^{1}$

The name card study derives from a weekly return card introduced by the Sentinel Stations in the Netherlands and later modified by ASPN. The pocketsized card, which was designed to take fewer than 60 seconds to complete, allowed clinicians to carry it from room to room as they saw eligible patients. Although a card study is essentially a survey, it is designed to be completed as patients are seen by those who provide the care. Card studies have undergone significant development by numerous researchers during the past 30 years and represent a wide array of data collection tools and methods. ${ }^{2-6}$

Despite their simplicity, card studies have contributed substantially to new standards of care for such diverse conditions as headache, miscarriage, 
and otitis media. ${ }^{7-12}$ For example, the publication of ASPN's card study on spontaneous abortion contributed to the evidence that uncomplicated spontaneous abortion could be managed safely without surgery. Using data from this study, Green et al found that card studies are as accurate as medical record review for identifying patients with specific conditions. ${ }^{13}$ In fact, the card study reporting method identified more patients with spontaneous abortion than were found on medical record review, probably because the reporting physician had knowledge of spontaneous abortions treated in other medical settings not recorded in the ambulatory chart.

The SNOCAP practice-based research networks (PBRNs) at the University of Colorado School of Medicine have considerable experience designing and conducting card studies. SNOCAP includes PBRNs focused on rural health care, urban and underserved primary care practices, and small, independent practices. Members range from single-physician offices to community health centers. SNOCAP card studies have examined a range of questions (Table 1).

We describe research questions that can be addressed with a card study, the 2 main types of card studies, the resources required, human subjects protection, implementation matter, and future considerations for card study research. Throughout this article we draw on SNOCAP's experiences to illustrate important concepts.

\section{CONDITION-SPECIFIC AND PREVALENCE CARD STUDIES}

Two basic types of card study methodologies-condition-specific cards and prevalence cards_-are derived from different research questions. In condition-specific

Table 1. Sample of Card Studies in SNOCAP

\begin{tabular}{|c|c|c|c|c|}
\hline Question & $\begin{array}{l}\text { Who Completed } \\
\text { Survey Cards }\end{array}$ & $\begin{array}{l}\text { No. of } \\
\text { Practices }\end{array}$ & $\begin{array}{l}\text { No. of } \\
\text { Clinicians }\end{array}$ & $\begin{array}{l}\text { No. of Cards } \\
\text { Distributed }\end{array}$ \\
\hline \multicolumn{5}{|l|}{ Condition-specific card study } \\
\hline $\begin{array}{l}\text { What factors influence changes in type } 2 \text { diabetes } \\
\text { treatment? }\end{array}$ & $\begin{array}{l}\text { Clinicians: card attached to all } \\
\mathrm{HbA}_{1 \mathrm{c}} \text { laboratory results }\end{array}$ & 19 & 88 & 483 \\
\hline $\begin{array}{l}\text { What factors influence changes in blood pressure } \\
\text { treatment in type } 2 \text { diabetes? }{ }^{16, a}\end{array}$ & $\begin{array}{l}\text { Clinicians: card attached to all } \\
\text { DMIl patient visits }\end{array}$ & 26 & NA & 778 \\
\hline \multirow{2}{*}{$\begin{array}{l}\text { To determine the adherence to Institute for Safe } \\
\text { Medication Practices recommendations regard- } \\
\text { ing sample provision in primary care }{ }^{17}\end{array}$} & Site visit & \multirow[t]{2}{*}{17} & \multirow[t]{2}{*}{ NA } & 585 (clinician) \\
\hline & $\begin{array}{l}\text { Clinicians and patients: when sam- } \\
\text { ple medications given out }\end{array}$ & & & 27 (patient) \\
\hline $\begin{array}{l}\text { What are the primary reasons a pharmacy calls to } \\
\text { clarify a prescription? }\end{array}$ & $\begin{array}{l}\text { Nurses: after every pharmacy pre- } \\
\text { scription clarification call }\end{array}$ & 22 & NA & 567 \\
\hline $\begin{array}{l}\text { What types of medical errors occur in ambulatory } \\
\text { primary care? }{ }^{19,20}\end{array}$ & $\begin{array}{l}\text { Practice clinicians, nurses, or staff: } \\
\text { anonymous or confidential cards }\end{array}$ & 33 & 475 & 708 \\
\hline $\begin{array}{l}\text { What are the presenting features of acanothosis } \\
\text { nigricans? }\end{array}$ & $\begin{array}{l}\text { Physicians: using a personal digital } \\
\text { assistant (PDA) }\end{array}$ & 2 & 20 & 311 \\
\hline \multicolumn{5}{|l|}{ Prevalence card study } \\
\hline $\begin{array}{l}\text { What is the impact of patient medication requests } \\
\text { on the clinical encounter? }{ }^{21, a}\end{array}$ & $\begin{array}{l}\text { Clinicians: card placed on every } \\
\text { chart at time of visit }\end{array}$ & 22 & 168 & 1,647 \\
\hline $\begin{array}{l}\text { What factors influence referral for Mental Health } \\
\text { services? a }\end{array}$ & $\begin{array}{l}\text { Clinicians: card placed on every } \\
\text { chart at time of visit }\end{array}$ & 30 & 170 & 1,693 \\
\hline $\begin{array}{l}\text { Description of clinical information missing at the } \\
\text { time of visit } 22, a\end{array}$ & $\begin{array}{l}\text { Clinicians: card placed on every } \\
\text { chart at time of visit }\end{array}$ & 32 & 253 & 1,614 \\
\hline \multirow{3}{*}{$\begin{array}{l}\text { What factors are associated with colorectal cancer } \\
\text { screening in rural primary care? }\end{array}$} & Clinicians & \multirow[t]{3}{*}{21} & 46 & \multirow[t]{3}{*}{570 (patient) } \\
\hline & Nurses/staff & & 63 & \\
\hline & Patients & & & \\
\hline \multirow{3}{*}{$\begin{array}{l}\text { What factors are associated with colorectal cancer } \\
\text { screening in rural primary care? }\end{array}$} & Clinicians & \multirow[t]{3}{*}{42} & 94 & \multirow[t]{3}{*}{851 (patient) } \\
\hline & Nurses/staff & & 118 & \\
\hline & Patients & & & \\
\hline $\begin{array}{l}\text { What is the prevalence of underinsurance in } \\
\text { ambulatory primary care? } ?^{23, a}\end{array}$ & $\begin{array}{l}\text { Patients: card given to every } \\
\text { patient on day } 1\end{array}$ & 37 & NA & 1,133 \\
\hline $\begin{array}{l}\text { Description of ambulatory care patients and } \\
\text { encounters }{ }^{24,25}\end{array}$ & $\begin{array}{l}\text { Clinicians: card for every other } \\
\text { patient until } 100 \text { completed }\end{array}$ & 7 & NA & 2,773 \\
\hline \multirow{3}{*}{$\begin{array}{l}\text { Description of smoking identification and cessa- } \\
\text { tion activities }\end{array}$} & Site visit & \multirow[t]{3}{*}{7} & \multirow[t]{3}{*}{ NA } & \\
\hline & Staff and clinicians & & & \multirow[t]{2}{*}{627 (patient) } \\
\hline & Patients & & & \\
\hline $\begin{array}{l}\text { What are the current practices for screening } \\
\text { women of reproductive age for alcohol abuse? }\end{array}$ & $\begin{array}{l}\text { Clinicians and nurses: clinician- } \\
\text { and patient-linked cards }\end{array}$ & & & $\begin{array}{l}\text { Funded, in } \\
\text { development }\end{array}$ \\
\hline
\end{tabular}


card studies, the respondent completes a card for each patient with a specified condition. This method is ideal for studying specific diseases or conditions, particularly when describing conditions that are less common or when highly detailed data collection on every patient would place undue burden on clinicians. Typically, data collection occurs during a 2- to 4 -week period with each clinician completing approximately 1 to 10 cards. A variation is to conduct the card study in the practice until a predetermined number of cards are completed. This approach will assure adequate responses from each practice, but may add extra study time to smaller practices.

For example, SNOCAP conducted a card study about the competing demands when caring for patients with diabetes, in which the clinician completed a card for each patient with diabetes seen in the office during a 2- to 4 -week period. ${ }^{16}$ In another study we attached a card to every hemoglobin $\mathrm{A}_{1 \mathrm{c}}$ (glycated hemoglobin) result sent to the practice from the laboratory during a single week. ${ }^{14,15}$ Clinicians completed the card when they reviewed their laboratory reports. Parchman and Abel had clinicians complete a card for each patient seeking care for with a skin infection over a 10 -month period. ${ }^{26}$

The condition-specific method is limited by a number of characteristics. First, it requires the respondent to remember to complete the card when he/she sees a patient with the condition. Second, the method does not necessarily obtain data on the denominator for the study, which means the condition prevalence within the practice or network cannot be determined. Third, although these cards are often designed to be completed during or immediately after the patient-clinician encounter, respondents sometimes wait until the end of the day to fill out their cards, which can introduce recall bias.

Frequently there is no published literature on the prevalence of health conditions in primary care. Most literature on prevalence relies on public health surveys or data from tertiary care centers. The second main type of card study, the prevalence card study, is usually used for conditions or phenomena that are more common or to determine the condition's prevalence in primary care. This method involves completing a card for each patient seen during a specified period (eg, a half-day or full-day clinic session). By collecting data on all patients seen, it is possible to determine the denominator and a rate of occurrence for the condition or phenomenon.

Prevalence surveys typically begin with a short section on patient demographics and one or more qualifying questions. If the patient does not have the specific condition or phenomenon, data collection is complete at that point. If the patient does have the condition, the clinician completes the remainder of the card. Typically the clinician must complete only a few questions for each patient.

For example, in our study about missing informa- tion, the clinician completed a card for every patient seen during 1 clinic session. ${ }^{22}$ The clinician answered 1 question about whether there was any missing information about the patient (laboratory studies, radiographs, consultations, etc). If the clinician answered no, the card was complete. If the answer was yes (in this case about $12 \%)$, the clinician answered several more questions. Another SNOCAP study examined direct-to-consumer advertising. ${ }^{21}$ During 1 day of patient care, the clinician completed a card for every patient seen. If the patient requested a medication during the visit, the clinician completed the entire card, otherwise, the clinician completed just the basic patient demographics. The use of a qualifying question maximizes the information about common primary care issues but does not require the clinician to answer unnecessary questions. Ralston et al determined the prevalence of tobacco usage by having clinicians answer questions for every patient seen during a 2 -week period. ${ }^{27}$ In that study, the investigators spread out data collection among clinicians to adjust for potential seasonal variation in patient visits. Prevalence studies can be biased if the clinical phenomena being studied are overrepresented in some practices or if they differ by the day of the week or time of year.

\section{Who Completes the Card?}

Card studies are completed by participating PBRN practices during a short period. Typically, the clinician

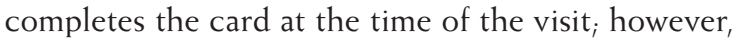
variations can minimize the disruption in the practice. Occasionally, the office staff or nurse can complete the patient demographics section at patient check-in, and the clinician then completes the rest.

Sometimes data must be obtained directly from the patient. Typically methods for collecting patientcompleted cards mirror the condition-specific and prevalence survey methods for clinicians, but variations exist. In one method, the card is given to every patient seen in a specified period (eg, 1 day or 1 week). Another method involves giving the card to patients with a specific condition or clinical problem. Patients can complete the card immediately and return it to a secure box in the practice (relying on patients to mail the card back significantly reduces response rates).

SNOCAP conducted a card study that gathered information from clinicians and patients about drug samples. ${ }^{17}$ The office staff attached a packet to the chart of each patient who had a visit that day. Clinicians completed a card about their use of drug samples during that visit. If the patient was given a drug sample, the clinician handed the patient a card to answer and return to the front desk. The data collected provided for a robust analysis of what clinicians and patients know and believe about drug samples. 


\section{Linking Data}

Depending on the study question, patient- or visit-level data can be linked to the practice or the clinician to make it possible to examine the association of practice or clinician characteristics with particular patient characteristics or patterns of care. It is then possible to adjust for clustering of patients within clinicians/ practices during statistical analysis. Linking patient data to clinician data requires a substantial amount of work and commitment from both the research staff and the practice. Supplemental Figures 1 through

4 (available online at http://annfammed.org/cgi/ content/full/9/1/63/DC1) provide examples of the different types of data linkage in card studies, and the Supplemental Appendix 1 (also available online at

http://annfammed.org/cgi/content/full/9/1/63/DC1) provides further detail on how to link data.

\section{RESEARCH QUESTIONS AND CARD STUDIES}

Some questions cannot be answered using a card study, and some clinical situations happen so infrequently it is not feasible to collect information about them using this method. Questions to consider when deciding whether a card study is the appropriate approach include:

1. What is the estimated prevalence of the condition? How will the season affect data or completion rates? If too few patients have the condition, you may have to stretch data collection over many months at the risk of practice burnout.

2. Do the potential study sites see the appropriate patient population? Do not ask about pregnancy if your practices deliver few babies.

3. Can clinicians answer questions about the condition at time of encounter or immediately thereafter? If they need to look up information, they likely will wait until later to answer.

4. Are the inclusion/exclusion criteria simple enough to make determinations? Will clinicians know the information for each patient? It is best to reduce the need to look elsewhere for the necessary patient data.

5. Can the card be completed in 1 minute or less? Can respondents complete the card without assistance? The goal is to minimize the work for people completing the card.

\section{IMPLEMENTING THE CARD STUDY IN PRACTICE}

It is important to develop a thorough implementation plan and discuss it with each practice. Each card study should include a written implementation plan that outlines the roles and responsibilities of each participating practice, clinician, and staff and describes the appropriate flow and allocation of forms. How will the card get into the clinician's hands? Which patients or charts should have a card? Where should completed cards be placed? A checklist for the practice contact is useful. If possible, we try to discuss the project at a practice staff meeting and encourage them to tell us how implementation will work best in their practice. In large practices or those with less research experience, we may have one of our research assistants facilitate the start of data collection.

The level of card study complexity is an important factor that determines the level of support a practice will require. Understanding how a particular card study fits into the practice flow is essential for a successful study and requires frequent communication with the practice. We encourage each practice to designate a staff person as the primary contact or so-called champion for our PBRNs to facilitate the process. This person is usually the same clinician or staff person for each study but may change based on the study topic.

For a prevalence survey, we recommend having a research staff member present first thing in the morning on the first day. Alternatively, a telephone call first thing in the morning can get the study off to a successful start. If a study requires a single day of data collection in each practice, it may require several weeks or months to complete data collection across the network.

For a study with linked data, each practice will have multiple packets of clinician-specific cards, which may require more assistance and training from research staff. Occasionally a research assistant maybe required to be present when the linkage is essential or particularly complex. As the practices become more accustomed to conducting card studies, they require less on-site assistance.

\section{ANALYZING CARD STUDY DATA}

After data cleaning, descriptive statistics (frequency distributions, means, standard deviation, rates) are generated for all variables of interest in the data set. To the extent possible, participants are compared with the target population by computing $95 \%$ confidence intervals on means and proportions for sociodemographic and clinical variables. Preliminary bivariate analyses are used to examine associations between potential independent variables (covariates, other predictors) and the outcome(s). Multivariate analyses generally come next, adjusting for covariates identified in bivariate analyses as statistically associated with the outcome (generally at $P<.20$ ) or considered clinically important.

Most PBRN data structures are hierarchical, with patients nested (clustered) within clinicians and clinicians nested within practices. Patients within practices 
may be more similar to each other than patients in different practices. Traditional statistical methods, such as logistic or linear regression, assume independence of observations. In the case of hierarchical (nested, clustered) data, however, these assumptions are often not met. It is important to choose multilevel analytic methods that adjust for clustering in PBRN studies. ${ }^{28}$

Another consideration in the design of PBRN studies concerns determining the number of subjects needed to address the research question. Again, it is important to determine the extent to which patients within practices are more similar than patients in different practices on the outcome variable of interest. This can be accomplished by using the intraclass correlation coefficient (ICC) from data collected or reported from other studies to adjust for clustering in estimating sample size needed to conduct the study. ${ }^{28}$

\section{TIMELINES AND COSTS OF CARD STUDIES}

Although card studies are known to be quick and cheap, they actually require months of planning and a considerable budget. In our experience, most card studies require 24 months from study idea to publication, and we find that card studies require about $\$ 10,000$ to $\$ 25,000$ to complete. Items to consider when developing a budget for a card study include the following: salary support for the principal investigator, project coordinator, and biostatistician/analyst; copying, envelopes, other office supplies; postage (both for sending out practice packets and for practices to return completed cards); ballot boxes to collect completed cards; long-distance fees, telephone lines, and fax lines for communicating with sites; mileage for visiting practices; incentive or compensation to practices for participation, including food for lunches, etc; and travel and meeting funds to present results at conferences or to present results to participating sites.

\section{Institutional Review for Human Subjects Protection}

Card studies are typically anonymous, and the perceived level of risk to patients is low; therefore, they qualify for exempt or expedited institutional review board (IRB) review. Care must be taken to comply with the IRB and HIPAA (Health Insurance Portability and Accountability Act) requirements for collection of protected health information. ${ }^{29,30}$ See Supplemental

Appendix 2 at http://annfammed.org/cgi/content/

fill full/9/1/63/DC1 for a more thorough discussion of human subjects protection and HIPAA compliance. Because local norms and interpretations differ, researchers should become familiar with these rules, as well as with any local or institutional requirements.
Electronic Data and the Future of Card Studies

We have limited our discussion to paper cards. The challenges and benefits of using personal digital assistants (PDAs) to collect data in a PBRN have been described elsewhere. ${ }^{31,32}$ SNOCAP conducted 1 card study using PDAs, but concluded that the problems with this method outweighed the benefits. Newer smartphone technology could change our conclusion.

Electronic health records (EHRs) offer an exciting opportunity to conduct studies without a card. One option is to use the HER to identify eligible patients and generate a card for every patient scheduled that day. Similarly, a card could be automatically created when a new diagnosis is reported or when the clinician orders a specific test, referral, or follow-up. We have not seen such features widely implemented in EHRs; however, the Distributed Ambulatory Research in Therapeutics Network (DARTNet) may offer opportunity to conduct real-time card studies in a meta-network of PBRNs with electronic medical records. ${ }^{33}$

\section{Benefits and Limitations}

Card studies allow clinicians and practices to compile large samples quickly with reasonable burden. For instance, a PBRN with 25 practices can quickly amass more than 1,200 cards by collecting only 50 cards from each practice. The card study is often a costeffective method for obtaining data quickly, engaging clinicians and staff in research, and describing components of clinical practice.

Card studies have several important limitations. One main limitation is their cross-sectional nature. Other limitations include the dependence on practice staff to follow protocols or reliance on clinicians to complete cards unprompted. These issues result in the potential for missing data or introducing bias into the data collection. Although attempts must be made to minimize missing or biased data, the benefit of card studies is that they are conducted in a large number of practices, which minimizes the impact of bias or missing data.

\section{DISCUSSION}

Card studies are still an excellent research tool for PBRNs. Card studies are relatively easy on practices and clinicians. They are relevant to clinicians, are relatively quick to develop and deploy, and can engage practicing clinicians in research without the need for clinicians to dramatically change their practice style. Card studies have a reasonable cost and a standardized analytical approach, and they are flexible and can be customized to desired research question and practice environment. Card studies can fit within the new and changing practice environment to test innovations in 
care management and practice redesign. Finally, card studies are great for generating pilot data. Although card studies have been around for more than 30 years, they represent a proven method for conducting excellent research in PBRNs.

To read or post commentaries in response to this article, see it online at http://www.annfammed.org/cgi/content/full/9/1/63.

Key words: Practice-based research; data collection; research methods; observational study; clustered data analysis, survey; community engagement; practice engagement

Submitted December 23, 2008; submitted, revised, July 19, 2009; accepted August 19, 2009.

\section{References}

1. Green LA. The weekly return as a practical instrument for data collection in office based research. Fam Med. 1988;20(3):182-184.

2. Binns HJ, Lanier D, Pace WD, et al.; Primary Care Network Survey (PRINS) Participants. Describing primary care encounters: the Primary Care Network Survey and the National Ambulatory Medical Care Survey. Ann Fam Med. 2007;5(1):39-47.

3. Vinson DV, Manning BK, Galliher JM, Dickinson LM, Pace WD, Turner BJ. Alcohol and sleep problems in primary care patients: a report from the AAFP National Research Network. Ann Fam Med. 2010;8(6):484-492.

4. Vinson DC, Galliher JM, Reidinger C, Kappus JA. Comfortably engaging: which approach to alcohol screening should we use? Ann Fam Med. 2004;2(5):398-404.

5. Dovey SM, Meyers DS, Phillips RLJ Jr, et al. A preliminary taxonomy of medical errors in family practice. Qual Saf Health Care. 2002; 11(3):233-238.

6. Kong AS, Williams RL, Rhyne R, et al.; PRIME Net Clinicians. Acanthosis Nigricans: high prevalence and association with diabetes in a practice-based research network consortium - a PRImary care MultiEthnic network (PRIME Net) study. J Am Board Fam Med. 2010;23 (4):476-485.

7. Becker L, Iverson DC, Reed FM, Calonge N, Miller RS, Freeman WL. Patients with new headache in primary care: a report from ASPN. J Fam Pract. 1988;27(1):41-47.

8. Becker LA, Green LA, Beaufait D, Kirk J, Froom J, Freeman WL. Use of CT scans for the investigation of headache: a report from ASPN, Part 1. J Fam Pract. 1993;37(2):129-134.

9. Becker LA, Green LA, Beaufait D, Kirk J, Froom J, Freeman WL. Detection of intracranial tumors, subarachnoid hemorrhages, and subdural hematomas in primary care patients: a report from ASPN, Part 2. J Fam Pract. 1993;37(2):135-141.

10. Anonymous. Spontaneous abortion in primary care. A report from ASPN. J Am Board Fam Pract. 1988;1(1):15-23.

11. Anonymous. An exploratory report of chest pain in primary care. A report from ASPN. J Am Board Fam Pract. 1990;3(3):143-150.

12. Froom J, Culpepper L, Green LA, et al.; Report from the International Primary Care Network (IPCN) and the Ambulatory Sentinel Practice Network (ASPN). A cross-national study of acute otitis media: risk factors, severity, and treatment at initial visit. J Am Board Fam Pract. 2001;14(6):406-417.

13. Green LA, Reed FM, Miller RS, Iverson DC. Verification of data reported by practices for a study of spontaneous abortion. Fam Med. 1988;20(3):189-191

14. Parnes BL, Main DS, Dickinson LM, et al.; CaReNet; HPRN. Clinical decisions regarding $\mathrm{HbA} 1 \mathrm{c}$ results in primary care: a report from CaReNet and HPRN. Diabetes Care. 2004;27(1):13-16.
15. Parnes $B$, Niebauer L, Holcomb S, et al. Provider deferred decisions on hemoglobin $A_{1 c}$ results: a report from the Colorado Research Network (CaReNet) and the High Plains Research Network (HPRN). J Am Board Fam Med. 2006;19(1):20-23.

16. Hicks PC, Westfall JM, Van Vorst RF, et al. Action or inaction? Decision making in patients with diabetes and elevated blood pressure in primary care. Diabetes Care. 2006;29(12):2580-2585.

17. Hansen LB, Saseen JJ, Westfall JM, Holcomb S, Nuzum DS, Pace WD. Evaluating sample medications in primary care: a practicebased research network study. Jt Comm J Qual Patient Saf. 2006;32 (12):688-692.

18. Hansen LB, Fernald D, Araya-Guerra R, Westfall JM, West D, Pace W. Pharmacy clarification of prescriptions ordered in primary care: a report from the Applied Strategies for Improving Patient Safety (ASIPS) collaborative. J Am Board Fam Med. 2006;19(1):24-30.

19. Westfall JM, Fernald DH, Staton EW, VanVorst R, West D, Pace WD. Applied strategies for improving patient safety: a comprehensive process to improve care in rural and frontier communities. J Rural Health. 200;20(4):355-62.

20. Pace WD, Fernald DH, Harris D, et al. Developing a taxonomy for coding ambulatory medical errors: a report from the ASIPS Collaborative. In: Henrikson K, Battles JB, Marks ES, Lewin DI, eds. Advances in Patient Safety: From Research to Implementation Volume 2 Concepts and Methodology. AHRQ Publication No 05-0021-2. Rockville, MD: Agency for Healthcare Research and Quality; 2005.

21. Parnes B, Smith PC, Gilroy C, et al. Lack of impact of direct-toconsumer advertising on the physician-patient encounter in primary care: a SNOCAP report. Ann Fam Med. 2009;7(1):41-46.

22. Smith PC, Araya-Guerra R, Bublitz C, et al. Missing clinical information during primary care visits. JAMA. 2005;293(5):565-571.

23. Voorhees K, Fernald DH, Emsermann C, et al; State Networks of Colorado Ambulatory Practices and Partners. Underinsurance in primary care: a report from the State Networks of Colorado Ambulatory Practices and Partners (SNOCAP). J Am Board Fam Med. 2008;21(4):309-316.

24. Parnes B, Main DS, Holcomb S, Pace W. Tobacco cessation counseling among underserved patients: a report from CaReNet. J Fam Pract. 2002;51(1):65-69.

25. Pace WD, Dickinson LM, Staton EW. Seasonal variation in diagnoses and visits to family physicians. Ann Fam Med. 2004;2(5):411-417.

26. Parchman ML, Munoz A. Risk factors for methicillin-resistant Staphylococcal aureus skin and soft tissue infections presenting in primary care: a South Texas Ambulatory Research Network (STARNet) study. J Am Board Fam Med. 2009;22(4):375-379.

27. Ralston S, Kellett N, Williams RL, Schmitt C, North CQ. Practicebased assessment of tobacco usage in southwestern primary care patients: a Research Involving Outpatient Settings Network (RIOS Net) study. J Am Board Fam Med. 2007;20(2):174-180.

28. Dickinson LM, Basu A. Multilevel modeling and practice-based research. Ann Fam Med. 2005;3(Suppl 1):S52-S60.

29. Pace WD, Staton EW, Holcomb S. Practice-based research network studies in the age of HIPAA. Ann Fam Med. 2005;3(Suppl 1):S38-S45.

30. Graham DG, Pace WD, Kappus J, et al. Institutional Review board approval of practice-based research network patient safety studies. In: Henriksen K, Battles JB, Marks E, Lewin DI, eds. Advances in Patient Safety From Research to Implementation, Volume 2 Concepts and Methodology. AHRQ Publication No 05-0021-3. Rockville, MD: Agency for Healthcare Research and Quality; 2005.

31. Pace WD, Staton EW. Electronic data collection options for practicebased research networks. Ann Fam Med. 2005;3(Suppl 1):S21-S29.

32. Galliher JM, Stewart TV, Pathak PK, Werner JJ, Dickinson LM, Hickner JM. Data collection outcomes comparing paper forms with PDA forms in an office-based patient survey. Ann Fam Med. 2008;6(2):154-160.

33. Pace WD, Cifuentes M, Valuck RJ, Staton EW, Brandt EC, West DR. An electronic practice-based network for observational comparative effectiveness research. Ann Intern Med. 2009;151(5):338-340. 